UDC $378(477): 81 ’ 243$

\title{
Olha O. Matvieieva
}

Doctor of Pedagogical Sciences,

Associate-professor, professor of the Department of Teacher Musical and Artistic Training

H. S. Skovoroda Kharkiv National Pedagogical University, Kharkiv, Ukraine

ORCID ID 0000000306637726

oamat@ukr.net

Valentyna M. Gryniova

Doctor of Pedagogical Sciences, Professor, head of the Department of Primary, Preschool and Professional Education H. S. Skovoroda Kharkiv National Pedagogical University, Kharkiv, Ukraine

ORCID ID 0000000230274622

kvn.grineva@gmail.com

Olena Yu. Kuznetsova

Doctor of Pedagogical Sciences, Professor, head of the Department of Foreign Languages №3

Yaroslav Mudryi National Law University, Kharkiv, Ukraine

ORCID ID 0000-0003-1156-1842

kvf2001@ukr.net

\section{APPLICATION OF ICT FOR EXPERT ASSESSMENT OF LATENT VARIABLES IN PSYCHOLOGICAL AND PEDAGOGICAL RESEARCH}

\begin{abstract}
The article analyzes the approaches to the study of latent variables in psychological and pedagogical research. The study confirms that some competences and personal qualities belong to the latent constructs (tolerance, readiness for life-long learning, value orientations, etc.) that are difficult to measure. To make their assessment more accurate and reliable, the expert evaluation method with ICT support is suggested providing for the involvement of a greater number of experts in the assessment process. The pedagogical expertise, covering a set of procedures necessary for getting collective expert opinion or assessment of a pedagogical object, phenomenon or process, is considered as the core of the expert evaluation method. The developed ICT assessment support for latent variables evaluation is oriented at the three-level classification of competences. It provides for determining the level of development of social-personal, general-scientific, instrumental, general-professional and specializedprofessional competences (the first level of classification) and their constituent structural parts (the second level of classification) as well as the level of acquired knowledge, skills, values and personal qualities (the third level of classification). The developed ICT assessment tool includes the data concerning the Author (Developer), Experts, Expert Assessment, the indices obtained as a result of the analysis of Expert Assessment (Coefficients). Experts are expected to assess the significance of smaller structural units correlating them with the larger ones. Initially, the development level of every individual competence in correlation with the social and professional competence is assessed in percentage; the acquisition of social and professional competence is taken as $100 \%$. Then the significance index of the competences that are the structural parts of every given competence is determined; the significance index of competence structural parts in reference to the relevant competence is assessed.
\end{abstract}

Keywords: latent variables; classification of competences; expert evaluation method; ICT assessment.

\section{INTRODUCTION}

Problem formulation. The change of the educational paradigm and the focus on the implementation of the competence-based approach in educational practice, stipulated by the adoption of the National Qualifications Framework [1], the Laws of Ukraine «On Education» [2] and «On Higher Education» [3], the Methodological Recommendations for the Development of the Framework of Vocationally Oriented Standards for Higher Education (Competence Approach) worked out by the Institute of Innovative Technologies and Education Content Modernization of the Ministry of Education and Science of Ukraine [4], set the task of determining the approaches and methods for the diagnostic assessment of competences developed in students. Thus, there is an evident need for the diagnostic tools ensuring assessment of competence development level. 
According to the Law «On Higher Education» (25.07.2018) competence is «a dynamic combination of knowledge and practical skills, ways of thinking, professional, ideological and civic qualities, moral and ethical values, that determines the ability of a person to successfully carry out professional and further learning activities and is the result achieved at a certain level of higher education» [3]. The Law «On Education» defines competence as «a dynamic combination of knowledge, skills, habits, ways of thinking, views, values and other personal qualities, that determines the ability of a person to successfully socialize, carry out professional and/or further learning» [2]. The definition given in the National Qualifications Framework is similar and points out that «competence is the ability of a person to perform a certain type of activity, manifested through knowledge, understanding, skills, values and other personal qualities» [1].

The study of scholarly works devoted to the analysis of competences (N. Bibik [5], V. Gryniova [6], etc.) has shown that competences and their structural elements refer to latent variables. However, some of them are measurable with a great degree of accuracy (knowledge, skills), while others are more difficult to measure.

As competences function as complex formations, a lot of aspects have to be considered during their development level assessment. It has to be done quickly and a large amount of information has to be processed and analysed. Nowadays ICT becomes an effective tool for the competence development assessment procedures. On the one hand, it provides for covering all structural components of any competence under examination. On the other hand, a lot of members of the teaching staff (teachers of different subjects) may be engaged in the assessment procedure, which makes the competence development assessment results more reliable and fair. Besides, it allows for the effective application of the method of expert assessment that adds to the accuracy of the assessment results.

We believe that the use of the developed ICT support materials for the evaluation of the latent variables and the method of processing the diagnostic assessment results (questionnaires, interviews, expert surveys, etc.) will facilitate the accuracy of competence development assessment.

Analysis of recent research and publications. The adjective «latent» (in Latin - latens) means something that is present but hidden and is not noticeable [7]. Nowadays, the theory of measuring latent variables is increasingly referred to in pedagogical research and other social systems (G. Bond Trevor [8], O. Maslak [9], B. Wright [10], etc.). From the very beginning of the development of the theory of measurement of latent variables, a great deal of attention has been paid to the study of measurement accuracy (G. Batygin [11], K. Bollen [12], G. Rasch [13]).

Ukrainian scholars have researched different aspects of competence assessment. For example, in order to assess the quality of teaching Y. Rashkevich considers the issues of the definition of competences and learning outcomes on the basis of questioning students and graduates [14]; L. Ognnovchuk highlights the issues of students' academic achievement assessment at the institutions of higher education applying the competence-based approach, generalization of the existing practical experience and development of a mathematical model for measuring the level of competence formation [15]; O. Shcherbina has developed some new tools for the assessment of competences in the Moodle system [16]; V. Troyanovskaya substantiates the results of adaptive testing as an alternative method of control and assessment of students' competences [17]; $\mathrm{V}$. Soloshchenko presents a comparative analysis of the criteria for assessing the foreign language competence of foreign students at various examinations in Germany [18].

V. Avanesov [19] emphasizes the need for the scientific approach to the study of latent variables. The scholar differentiates between 2 terms: «latent quality» and «latent variable». «Latent quality is a concept, it is not a variable phenomenon. Qualities are inherent in people; constructs exist in the minds of researchers ...» [20]. K. Bollen [12] distinguishes between informal and formal types of latent variables. The hypothetical variables that arise in the mind of a researcher are referred to the informal type. They are not observable and therefore are not measured. The search for such variables is carried out using exploratory mathematical methods (exploratory factor analysis, cluster analysis, multidimensional scaling, etc.), that are used to reduce the number of observed features and their classification. The hidden variables of the formal type serve to establish 
a correlation connection between the observed variables. A hidden variable does not manifest itself until the observed phenomena begin to interact. The given aspect provides for the probability nature of manifestations of latent variables.

G. Batygin writes that «latent variables have an infinite number of manifestations, each of which is characterized by a different level of relevance - the degree of meaning closeness to a given latent variable. Therefore, the researcher is forced to choose from the explicit variables those that are most relevant» [11, c. 54]. On the basis of analysis of the issues of latent variables measurement and the reasons for their measurement G. Batygin distinguishes three specific features: a) latent variables do not manifest themselves directly, therefore, they can be artificially constructed by means of using collective notions for non-existent items; b) the nature of differentiation between the explicit and latent features is conditional and relative, since in the course of a detailed study any explicit variable may turn out to be latent, and the latent variable becomes explicit only in case of an operational interpretation; c) explicit variables do not exist separately, they reflect the deepest inner phenomena [11].

Despite the absence of the scholarly agreed theoretical justification of the notion of «latent variable», R. Ostapenko [21] suggests the classification of latent variables emphasizing their different aspects:

1. The difference between latent variables depends on the type of empirical perception of the phenomena. For example, the methods of factor analysis are divided into exploratory (investigative) and confirmatory. During the investigative factor analysis, a researcher does not know how many factors need to be extracted from the original data. To find out the number of factors, either formal (Kaiser criterion, etc.) or informal criteria, based on the principle of clear interpretation (Occam's razor), are used. Performing the confirmatory factor analysis, an investigator seeks to confirm the hypothesis of a latent variable or structure.

2. It is necessary to distinguish between latent variables that are determinant (the cause of something) or determined (the consequence of something). For example, in Structural Simulation (SEM) «in causal pairs, dependent and independent variables are manifested as both latent and observed variables in different combinations. Thus, both latent and observed variables can be determined by latent and observed variables. It is also possible that a determined variable, in turn, can determine some third variable» [22, p.131].

3. Latent variables are also classified as metric or nonmetric. In the classical factor analysis (Ch. Spirman) the latent and observed variables are referred to a metric type (the correlation scale and interval scale). According to the theory of pedagogical measurement, the observed variables belong to a nonmetric type (the correlation scale and interval scale). In the cluster analysis the latent and observed variables are referred to a nonmetric type.

4. Latent variables may vary in the degree of data «explanation». Various elements such as the size of the sample under study, the existence of missed data, the number of indicators and their correlation, etc. affect this aspect.

In Psychology, L. Vygotsky's concept of the zone of proximal development gives insight into latency. The zone of actual development comprises existing knowledge and skills, while the zone of proximal development is represented by latent knowledge that is not explicit and visible (for example, when solving mathematical problems). But if those tested are given additional, guiding questions, then their existing but functioning as latent knowledge turns out to be explicit.

In scholarly works on the accuracy of measuring latent variables in education (on the basis of G. Rasch model), the learners' knowledge and skills as well as their development level are considered to be latent. Scholars T. Anisimova, A. Davletova, A. Zhamalova, O. Maslak, S. Osipov define and analyse «success-oriented motivation», «tolerance», etc. as latent variables [23], [24]. To measure such latent variables they use the method of simulation modeling and the method of linear scale [23], [24].

The method of modeling is used to determine professional activity focused on competences. A lot of competence models have been implemented in the European institutions of higher education. The International Department for Standardization of teaching, achievements and 
education suggests considering such competence elements as acquired knowledge, skills, habits and learning achievements as those that are measurable [25, p. 20]. Having analysed the works of T. Anisimova, A. Davletova, A. Zhamalova, O. Maslak, S. Osipov, we refer such competences as positive attitude to other cultures, ethical obligations, striving for quality (Tuning Programme) [14], tolerance, ecological literacy, etc. (the Methodological Recommendations for the Development of the Framework of Vocationally Oriented Standards for Higher Education (Competence Approach) of the Institute of Innovative Technologies and Education Content Modernization of the Ministry of Education and Science of Ukraine) [4] to the latent variables. According to R. Ostapenko classification they may function as both determining and determined (for example, the latent competence of «lifelong learning» can be determined by such explicit variable as motivation to success). Besides, according to the theory of pedagogical measurement the explicit variables refer to the nonmetric type.

We believe that in order to ensure and increase the level of objectivity of the assessment of latent variables in psychological and pedagogical research the expert evaluation method with ICT support is worth using. The analysis of scholarly works and our experience in competence development assessment proves that the expert evaluation method provides for accuracy and reliability of evaluation results.

The method of expert evaluation is one of the most important methods of diagnostic assessment. It provides for carrying out a quantitative or qualitative assessment of competence formation, as well as for measuring other qualities inherent to students and for reducing the subjective component in the process of assessment. The methods of expert evaluation currently used in Pedagogy are quite varied. A lot of scholars have devoted their works to their study and analysis (N. Borytko [26], O. Mikhailychev [27], S. Shyshov [28]).

The basis of the method of expert evaluation is pedagogical examination, which includes a set of procedures necessary for obtaining a collective expert opinion or assessment of the pedagogical object, phenomenon or process. Typically, highly qualified teachers, scholars and managers are involved in evaluating the results.

Various types of the method of expert evaluation are applied: the method of expert collective assessment (the commission method, the method of «pedagogical consultation», the method of group expert evaluation (the Delphi method), etc.). Individual expert assessments and opinions can be obtained by questioning, interviewing or during conversations. The method of expert evaluation is effective for the development of didactic tests on different subjects, for the examination of the educational programme and its structural topics and sections, etc. Besides, it provides an important tool for determining the development level of students' latent competences that are difficult to quantify.

The use of the method of expert evaluation aimed at the diagnostic assessment of student's competence development involves meeting the following requirements:

- well-defined and unambiguous definition of the purpose, subject and field of application of the methodology with the obligatory instructions as for the qualifications of experts and their number;

- preliminary check of experts' readiness to follow the instructions;

- the possibility of re-examining the assessment results by means of documenting (recording) the intermediate stage results and their processing [26].

Unresolved aspects of the problem. The analysis of scientific research, dealing with the issues of determining the accuracy level of education results (V. Bespalko [29], M. Yevtuch [30], O. Maiorov [31], E. Mikhailychev [27], etc.) allows us to come to the conclusion that they cover:

- knowledge, skills, habits, development of general and special professional skills;

- the indicators of one's personal development (the level of development of personality's intellectual, emotional, volitional, motivational aspects, cognitive and other interests and needs, the development of a stable motivation for learning, creativity, as well as moral, aesthetic, physical, environmental development characteristics);

- students' individual characteristics (temperament, the mode of acquisition of the 
educational material, memory type, etc.).

The problem of assessment of the level of competence development in a graduate is being analysed in psychological and pedagogical research, however it has not been solved yet. The difficulty is directly attributed to the fact that a number of students' competences and personal qualities refer to the latent constructs (tolerance, readiness for lifelong learning, value orientations, etc.). Thus, there is a need for the development of assessment methods, techniques and materials, including the ICT assessment tools, ensuring reliability and accuracy of the assessment procedures. Besides, there is an evident lack of ICT-based assessment support oriented at the evaluation of latent variables and providing for the application of the method of expert evaluation.

The present-day transformations in higher education, new educational realities make scholars realise the shortcomings of traditional methods and procedures of control and assessment (oral exams as the main and often the only tool of control), their insufficiency and inconsistency with the requirements of the time:

- the competitiveness in the employment market has increased the importance of diagnostic assessment and evaluation procedures, allowing for determining not only the level of acquired abstract theoretical knowledge, but also the level of development of graduates' professionally-oriented practical skills (competences);

- the development of new information technologies, in particular of Internet technologies, has facilitated an easy access to ready-made answers to exam and test control data, to course papers and theses, which influences the reliability of learning results;

- some inertia in introducing new technological procedures for diagnostic assessment and evaluation (computer testing or computer-based coordination of independent expert evaluations) is the result of still existing poor technical equipment of the institutions of higher education (lack of computers) or poor computer literacy of the teaching staff, etc.

The purpose of the article is to propose an ICT-based tool for expert evaluation of students' competence development focused on the assessment of competence latent variables.

\section{RESEARCH RESULTS}

The development and application of ICT support materials for determining the development level of competences as latent variables was oriented at the three-level classification (from the Latin «classis» - the category and «facere» - to do) of competences suggested by O. Matvieieva [32], focusing on the understanding of classification as «a specific case of applying the logical operation of the distribution of the concept content, which represents some complex of meaningful distributions (the distribution of certain classes of material or non-material objects, their types, the distribution of those types, etc.)» [7, c. 348]. The given classification of competences is based on the definition of the term «competence» given in the National Framework of Qualifications [1], the Laws of Ukraine «On Education» [2] and «On Higher Education» [3], the Methodological Recommendations for the Development of the Framework of Vocationally Oriented Standards for Higher Education (Competence Approach) worked out by the Institute of Innovative Technologies and Education Content Modernization of the Ministry of Education and Science of Ukraine [4], in the studies of Ukrainian and foreign scholars (N. Bibik [5], V. Gryniova [6], O. Kuznetsova [33], O. Matvieieva [32]).

According to the Methodological Recommendations for the Development of the Framework of Vocationally Oriented Standards for Higher Education (Competence Approach) worked out by the Institute of Innovative Technologies and Education Content Modernization of the Ministry of Education and Science of Ukraine, the quality of training of a graduate is determined by the developed level of competences: social and personal (SPC), general scientific (GSC), instrumental (IC) and professional competences (general-professional - GPC, specialized-professional - SPC). Similar social-personal, general scientific and instrumental competences are formulated for graduates of different specialities, whereas professional competencies are determined according to 
the students' speciality and educational qualification level. The analysis of instrumental and general scientific competences provides for the conclusion that their acquisition is aimed at obtaining a system of knowledge and skills in the relevant disciplines or groups of disciplines. They are easier to be assessed with high degree of accuracy. However, social-personal competences characterize a student as a person and a subject of professional activity and function as latent variables.

The social-personal competences encompass: understanding and assimilation of ethical norms of behavior in relation to other people and environment (the principles of bioethics); understanding of the need for and observance of healthy lifestyle standards; readiness for lifelong learning; ability to criticize and being self-critical; being creative, ability to think systematically; adaptability and sociability; persistence in achieving the goal; being responsible for the quality of the work done; tolerance; ecological literacy [4]. The development of these competencies testifies to students' acquisition of the system of knowledge about the social reality and their «self», their understanding of the modern world and their place in it, the system of social and interaction skills, the behavior patterns in typical situations that allow a person to adapt adequately and quickly and make the right decisions. Consequently, the social-personal competences of a specialist in any field of knowledge are aimed at ensuring their standard of living, interaction with other people, readiness for constant professional development and successful creative self-realization. At the same time, they function as latent variables, and to assess and evaluate the level of their development objectively certain pedagogical assessment tools with ICT support have to be worked out.

In accordance with the provisions of formal logic, the term «competence» is an integrated term reflecting the manifestations of a variety of subject's characteristics. By content competences are abstract concepts. Depending on the content and scope of these concepts, they are divided into two categories: comparable and incomparable. The terms «competence» (countable, being developed) and «competence» (uncountable, developed and existing) are comparable, since they reflect the phenomena relevant to the same life/professional sphere and share common characteristics (concerning both quality and quantity aspects). They are also compatible, since they are characterized by common content and quantity features [34, p. 45].

As the quality of education of a graduate is determined in terms of the level of development of his/her social-professional competence, consisting of social and personal, general scientific, instrumental, professional competences and their components, the assessment methods and tools have to focus on the techniques ensuring high level accuracy of measuring every structural element of a given competence.

We have developed the ICT assessment tool focused on competences to be acquired by graduates. The developed ICT assessment procedures are oriented at the classification of competences based on the following assertions: 1) competence presupposes acquisition of generalized comprehensive knowledge, skills and habits that ensure the future specialist's readiness to define and solve complex non-standard professional tasks and allows a person to reveal his/her value-related attitude to the profession and demonstrate his/her professionally-oriented personal qualities; 2) structurally, the term «competence» is understood as a summation of competences (sub-competences) in certain areas; 3) structural elements of every competence are knowledge, skills and habits, manifested in students' results in learning, as well as developed value-based attitudes and personal qualities; 4) competencies can be differentiated as general, developed while studying different curriculum modules or disciplines, and specific, developed while doing only one curriculum module or discipline. For example, the competence of being able to communicate in the native language in written and oral form (C1-1) is a general one, developed while studying different disciplines, and is characterized by its own structure. Specialized-professional competences refer to specific ones, since their development takes place during studying separate professionally-oriented curriculum disciplines; 5) the competences that are developed in students during their study of curriculum disciplines are «the basic» ones, the competences, the acquisition of which is not directly relevant to the curriculum content, are «the accompanying» ones; social-personal and instrumental competences refer to this group; 6) each competence is characterized by its own 
specific development level - the level of development of knowledge, skills, values and personal qualities, determined at different stages of the educational process (exams, tests, modular control).

Every competence is viewed as consisting of such structural elements as knowledge, skills, habits, value orientations and personal qualities. Thus, we can define them as being structurally similar but varying in terms of their content. Knowledge and skills as the structural components of a competence can be assessed with a high level of accuracy. This fact is confirmed by the scholarly articles of V. Avanesov [19], V. Bespalko [29], M. Yevtuch [30], O. Maiorov [31], Ye. Mihaylychev [27] and others. However, objective assessment of such latent variables as value orientations and personal qualities is more complicated. In this case the engagement of a bigger number of experts in the assessment procedures and analysis of their expert opinions might provide more reliable evaluation results of the level of competence development in students.

To carry out the expert evaluation of the system of competencies under study, ICT support materials have been developed, providing for the involvement of experts who are specialists in different curriculum disciplines. The experts involved in the diagnostic procedures are expected to be highly skilled, competent, unbiased and they have to realise the significance and responsibility of their activities. Particular attention has been paid to competence assessment checklist, based on the classification of competences suggested by O.Matvieieva [32].

The experts involved in the diagnostic procedures are expected to be highly skilled, competent, unbiased and they have to realise the significance and responsibility of their activities.

The developed survey database contains information about the Author (Developer), the Experts, the Expert Assessment, as well as the indices obtained as a result of the analysis of Expert Assessment (Coefficients).

To administer processing and assessment of the results, a user database, providing for the distribution of rights and functions and ensuring protection from unauthorized changes, has been created. The registration process, being administered by the moderator, allows the Experts to get access to the programme data.

The programme block is designed to fill in the hierarchically structured database and find out significance coefficients of latent properties of the investigated object.

Project database structure.

The project database consists of the following blocks:

1. The «User» block, containing the data about registered users and their access levels (Developer, Expert, User).

2. The «Competence structural components» block is compiled by the Developer and contains the list of competences for assessment. Besides, the block contains the information on the number of experts who have completed the questionnaire and results of the processed data.

3. The «Expert Assessment» block is filled in by an Expert and contains the marks given by that Expert during the diagnostic procedure. Experts assess the significance of smaller structural units correlating them with the larger ones. Initially, the development level of every individual competence (SPC, GSC, IC, etc.) in correlation with the social and professional competence is assessed in percentage, the acquisition of social and professional competence is taken as $100 \%$. Then the significance index of the competences that are the structural parts of the given competence is determined and the significance of competence structural parts in reference to the relevant competence is assessed. The average arithmetical index of the Experts' assessment results is determined and then the final Expert assessment form is displayed.

4. The «Main» block combines all assessment block data for further processing and use.

The structural elements are presented hierarchically, having the three-level structure, the example is given in Figure 1. Indexing of structural elements by converting «the Structure Level» and «the Level Component Number» into the identifier line of «the X.X.X.X.X» type where X denotes the position in the levels. 


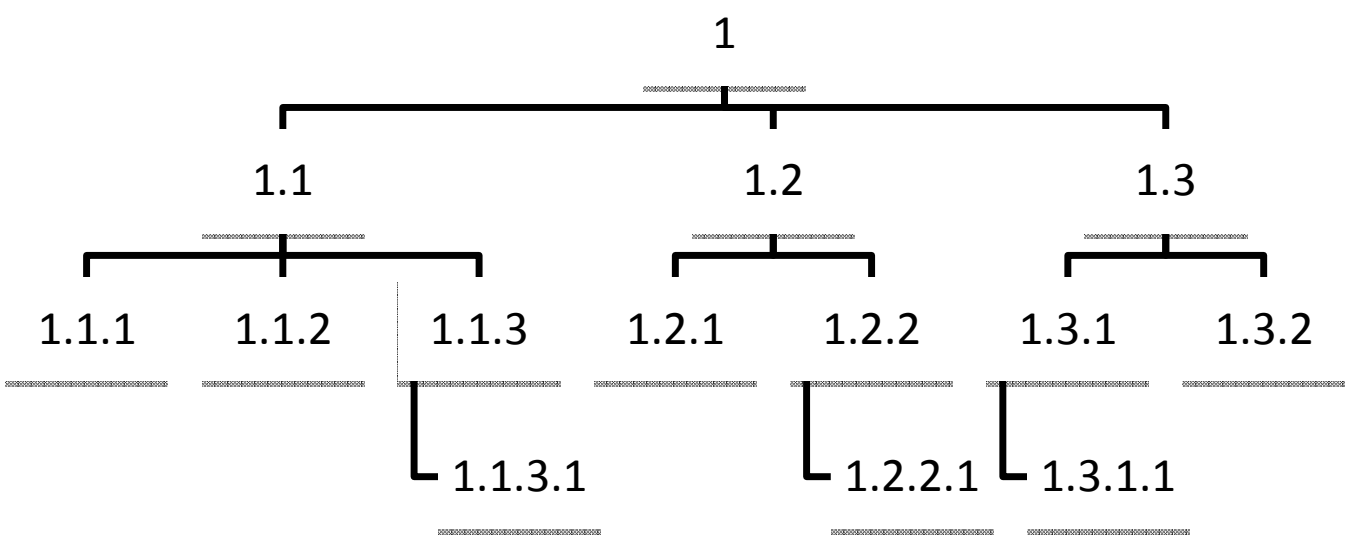

Fig.1. The structure of competence assessment list for experts

The software unit contains four screen forms. Figure 2 shows the screen format of the authorization form, allowing for logging in and registration.

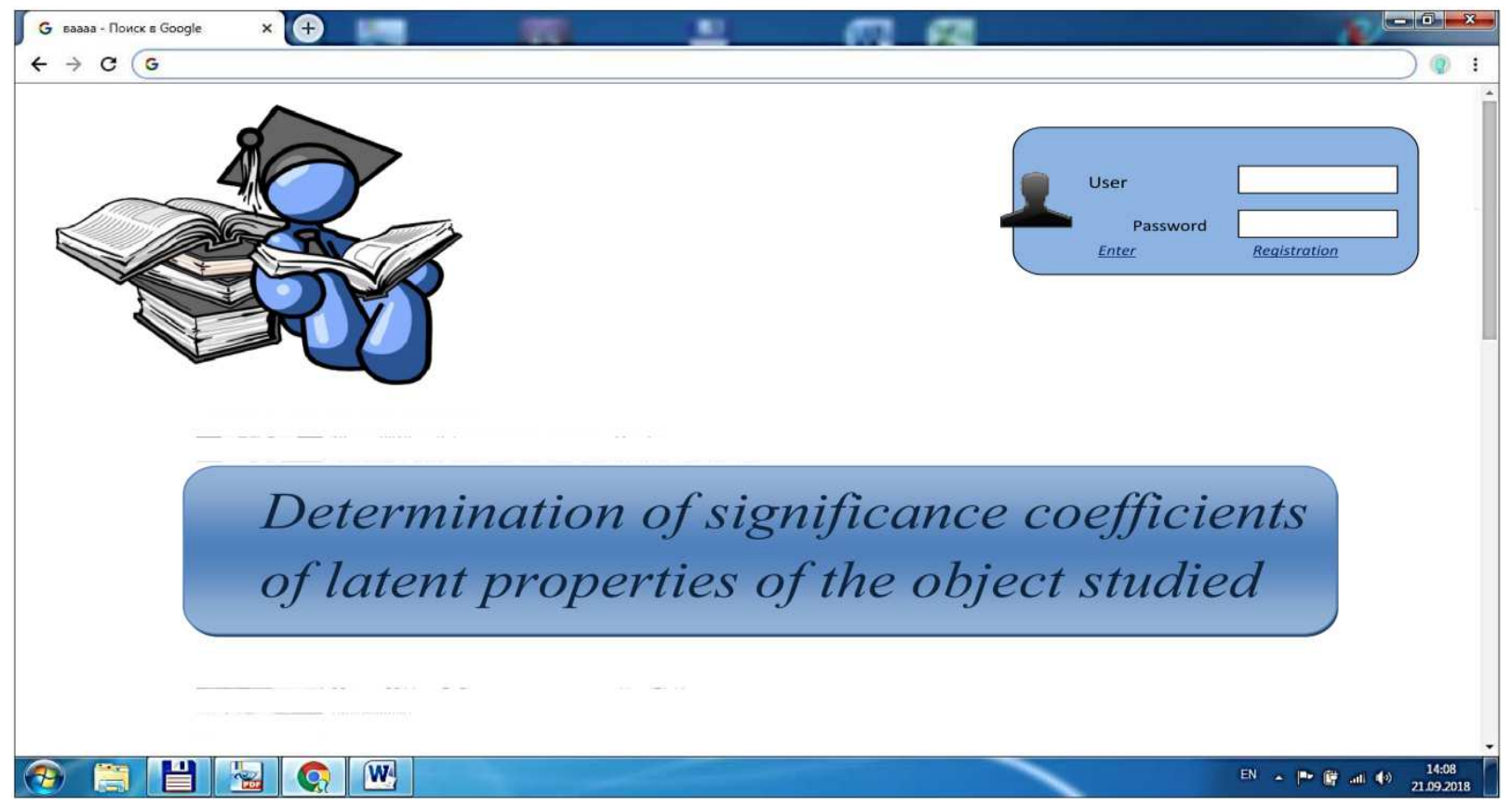

Fig. 2. The authorization form

Depending on the user rights the access is offered in three modes: Developer, Expert and User. Figure 3 shows the structure form of the latent properties of the object studied.

Only the Developer has access to this form.

The choice of the required line of the list of latent properties of the object studied is carried out with the use of the «up» and «down» arrows, the «+» button adds a line to the corresponding part, the «X» sign removes the selected line from the area. In case of any change in the group list, the lists of the subgroup data and properties also change. The subgroup selection causes the change of the list of properties displayed, showing the list of properties of the corresponding subgroup. 


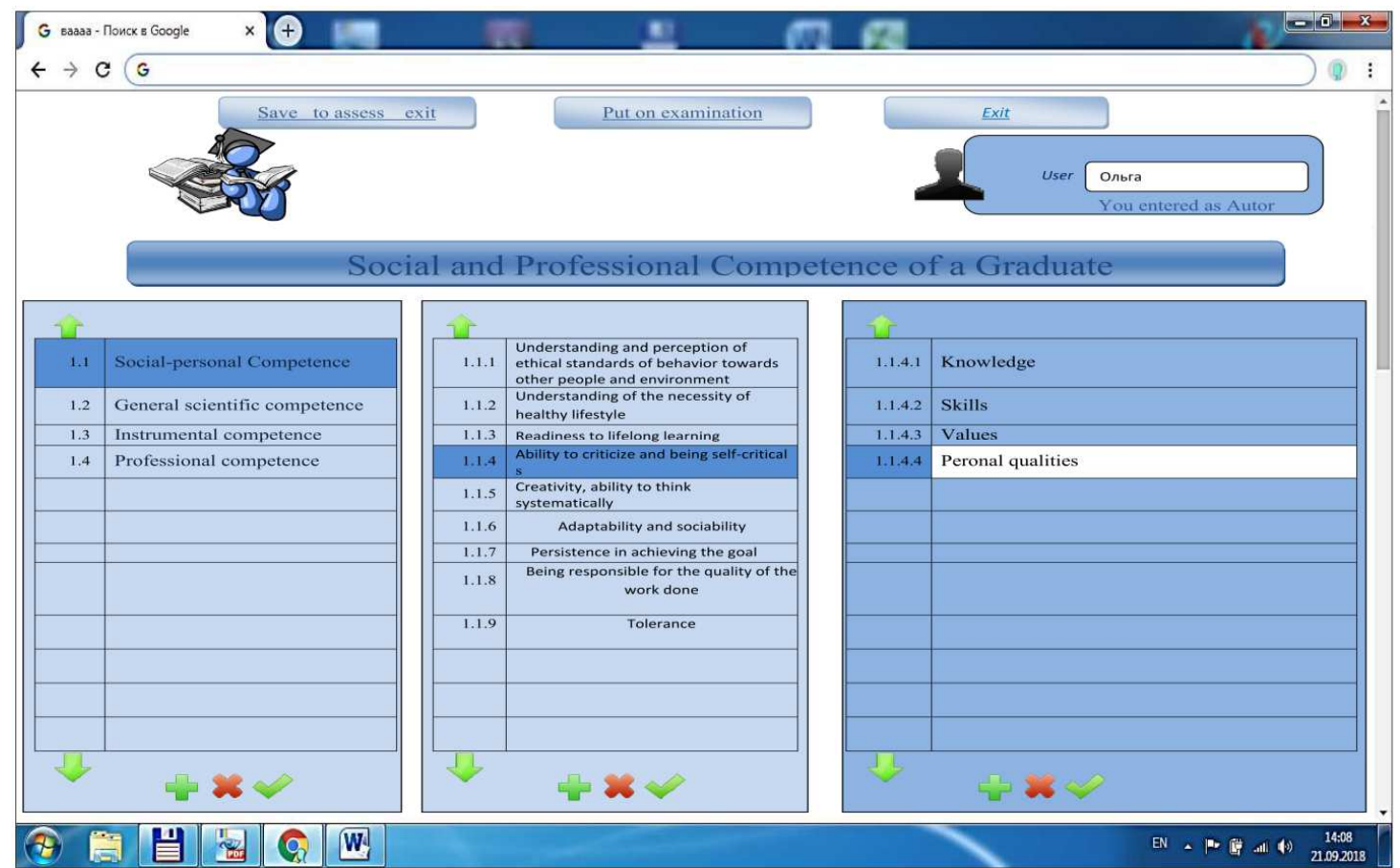

Fig. 3. The structure form of the latent properties of the object studied

Figure 4 shows the form for filling in the significance coefficients of the latent properties of the object studied.

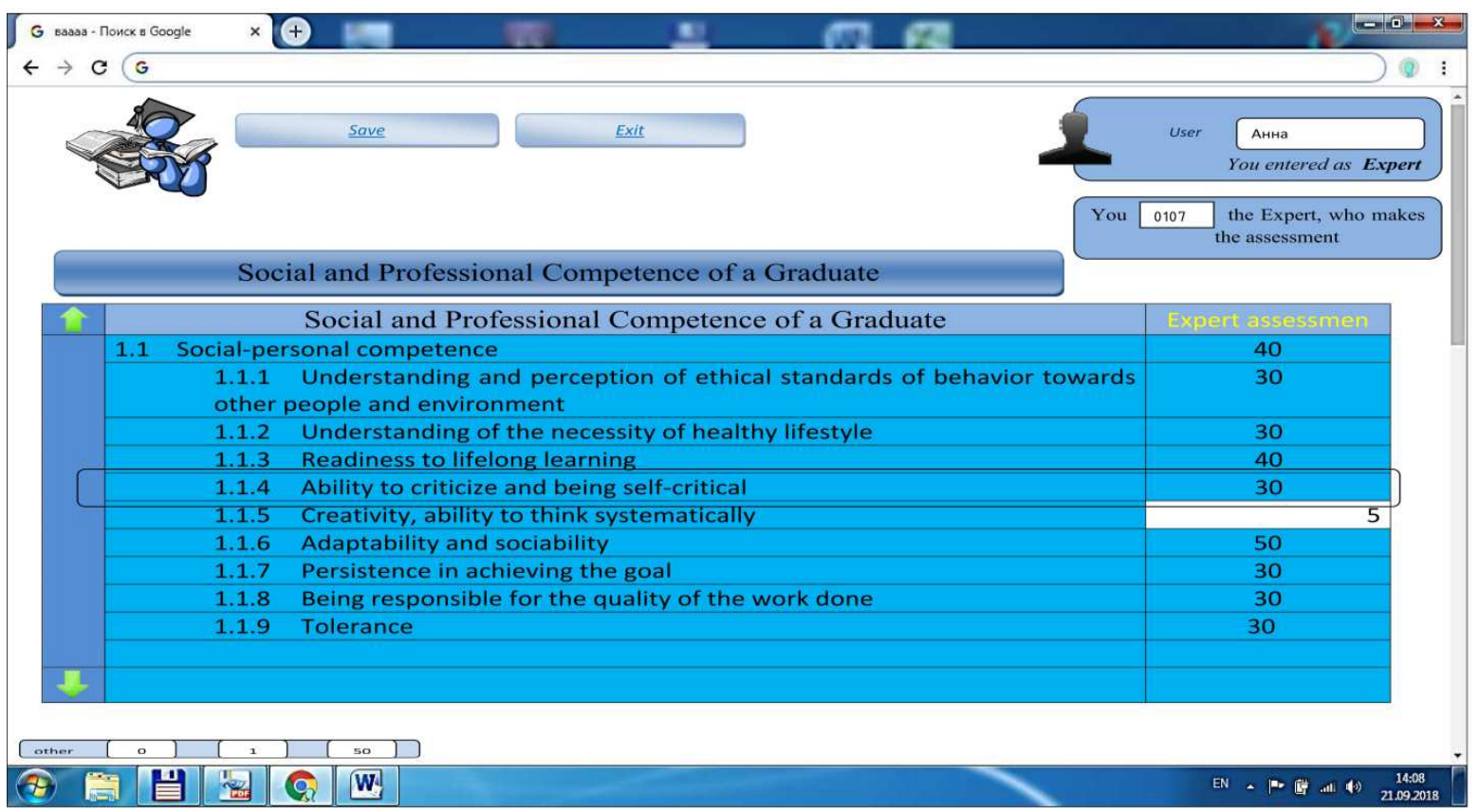

Fig. 4. The form for filling in the significance coefficients of the latent properties of the object studied

The Developer and an Expert have access to this form.

The selection of the required element is carried out with the use of the «up» and «down» arrows. The significance coefficient is marked against every structural element; the data concerning the significance coefficient of selected elements allowing for their correction are shown at the bottom of the form. 
The calculating technique is based on the principle that the sum of the significance coefficients in the group should be equal to 100 . To ensure this, the sum of unrecorded significance factors that are designated as «Other» is displayed at the bottom of the screen.

Figure 5 presents the form of significance coefficient processing.

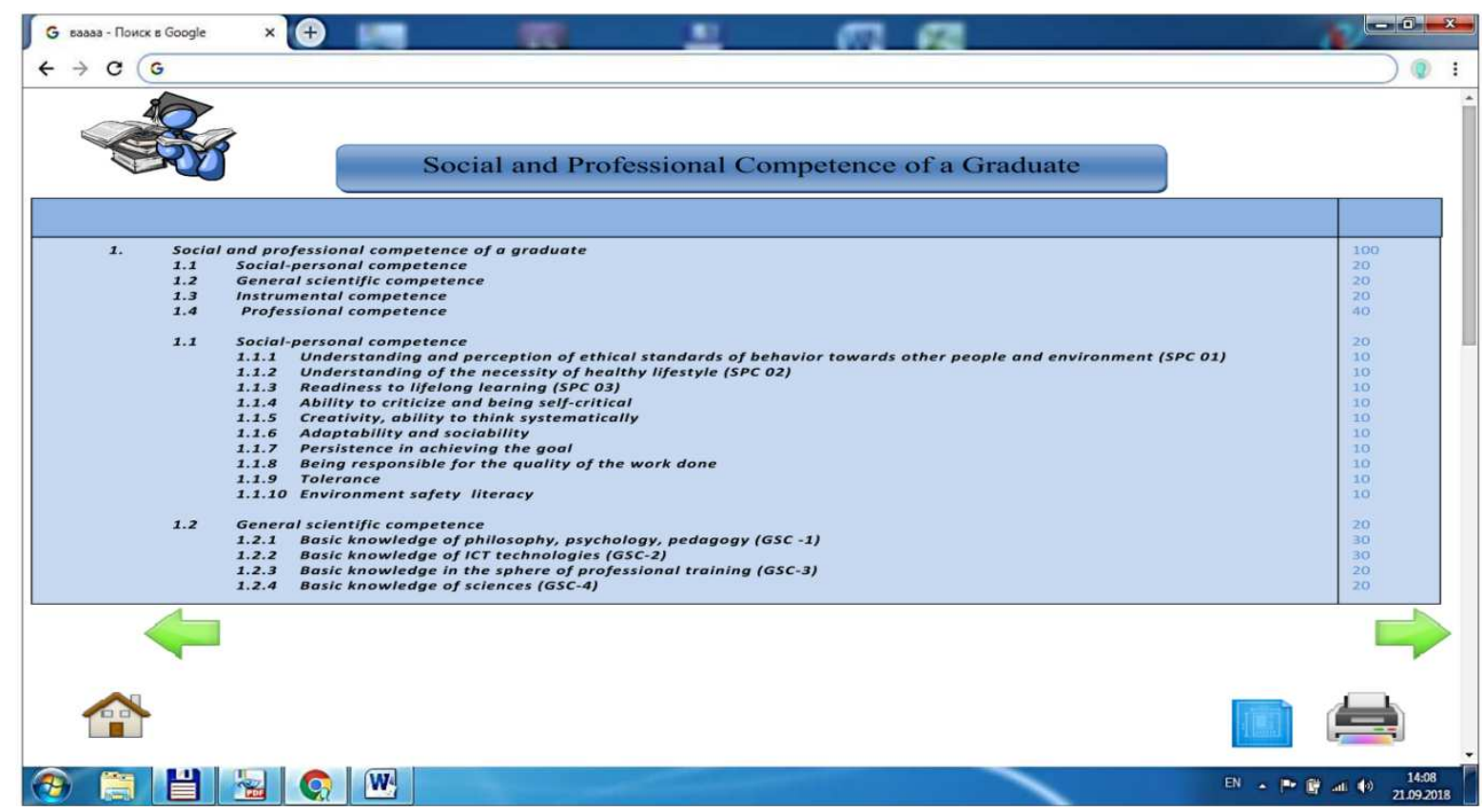

Fig. 5. The form of significance coefficient processing

This form is available to all users.

After the author of the project (Developer) has entered the form of the structured questionnaire, the resource page offers the link to the questionnaire (the link allows to see who the questionnaire has been developed by). By clicking on the link, the experts can start to fill in the coefficients. After entering the coefficients, using the method of statistical analysis the data processing procedure takes place, providing for getting average significance coefficient indicators.

\section{CONCLUSIONS AND FURTHER RESEARCH}

The official documents define the goals and quality of higher education in the state within the framework of competence development. However, some competences and their structural elements refer to latent structures and to measure their development, appropriate and reliable assessment tools have to be worked out. The analysis of approaches to the definition and research of latent variables in psychological and pedagogical research has shown that both Ukrainian and foreign scholars devote their studies to working out measuring instruments for determining the development level of these constructs. However, the assessment of the level of competence development in a graduate is a problem that has not found an unambiguous solution in psychological and pedagogical research yet.

Our study confirms that some competences and personal qualities belong to the latent constructs (tolerance, readiness to life-long learning, value orientations, etc.) and teachers often face difficulties evaluating them. To increase the level of their assessment objectivity the expert evaluation method with ICT support is suggested providing for the involvement of a greater number of experts in the assessment process. The proposed ICT assessment tool is oriented at the three-level classification of competences and provides for determining the level of development of socialpersonal, general-scientific, instrumental, general-professional and specialized-professional competences (the first level of classification) and their constituent structural parts (the second level of classification) as well as the level of acquired knowledge, skills, values and personal qualities (the third level of classification). 
The proposed ICT assessment tool presents an effective means to: engage more experts in the assessment procedures, make the evaluation data more reliable and unbiased, measure competence development level, provide information on ongoing competence acquisition level, highlight the constructs that require additional development and training, determine the level of competence development at different stages of the process of learning.

The developed ICT assessment support includes the data concerning the Author (Developer), Experts, Expert Assessment, the indices obtained as a result of the analysis of Expert Assessment (Coefficients). The programme block is designed for filling in a hierarchically structured data basis and processing of significance coefficients of competence latent variables.

The issues that are worth further study and research are the aspects of the accuracy of measurement of graduates' specific latent variables of competence development as well as working out other diagnostic tools for the assessment of such latent variables as success-oriented motivation, tolerance, the ability to think systematically, etc.

\section{REFERENCES (TRANSLATED AND TRANSLITERATED)}

[1] Postanova Kabinetu ministriv Ukrayiny`. (2011, ly`stop. 23) «On Adoption of the National Qualifications Framework». [online]. Avalaible: http://zakon0.rada.gov.ua/. (in Ukranian).

[2] Verxovna Rada Ukrayiny`. (2017, veres. 5). Zakon № 2145-VIII, «On education». [online]. Avalaible: http://zakon.rada.gov.ua/laws/show/2145-19/ (in Ukranian).

[3] Verxovna Rada Ukrayiny`. (2014, ly`p. 7). Zakon № 1556-VII «On higher education». [online]. Avalaible: http://zakon.rada.gov.ua/laws/show/1556-18. (in Ukranian).

[4] V. Gulo and al., Methodical recommendations on the development of component sectoral standards of higher education (competence approach). Kyiv, Ukrayina: Insty`tut innovacijny`x texnologij i zmistu osvity`MON Ukrayiny`, 2013. (in Ukranian).

[5] N. M. Bibik, «Benefits and risks of introducing a competency approach in school education», Ukrayins`ky $j$ pedagogichny j zhurnal. № 1. p. 47-58, 2015. (in Ukranian).

[6] V. M. Gry`n'ova, «Competent approach to the modernization of national education: the essence and terminology», Ridna shkola. № 4 (1036), p. 20-26, 2016. (in Ukranian).

[7] V. S. Stepin, Philosophical encyclopedic dictionary. Moskva, RF: Mysl', 2010. (in Russian).

[8] G. Bond Trevor, and Christine M. Fox, Applying the Rasch Model: Fundamental Measurement in the Human Sciences. New Jersey, USA: Mahwax, 2001. (in English).

[9] A. A. Maslak, Measurement of latent variables in socio-economic systems: theory and practice. Slavyansk-naKubani, RF: Izdatel'skij centr SGPI, 2007. (in Russian).

[10] B. Wright, and M. Stone, Making measures. Chicago, USA: The Phaneron Press, 2004. (in English).

[11] G. S. Batygin, Lectures on the sociological research methodology. Moskva, RF: Aspekt Press, 1994. (in Russian).

[12] K. A. Bollen, «Latent variables in psychology and the social sciences», Annu. Rev. Psychol, vol. 53, p. 605-634, 2002. (in English).

[13] N. Bezruczko, Rasch Measurement in Health Sciences. Minnesota, USA: JAM Press, Maple Grove, 2005. (in English).

[14] Yu. Rashkevy`ch, Competencies definition and formulation of learning outcomes for students and staff interviewing for the purpose of teaching evaluation. [online]. Avalaible: http://www.ihed.org.ua/images/pdf/4_Rashkevych_10_10_2014.pdf. (in Ukranian).

[15] L. M. Ognivchuk, «Academic achievements assessment of students of higher educational institutions on the basis of competent approach», Osvitologichny`j dy`skurs, № 3 (7). p. 154-165, 2014. (in Ukranian).

[16] O. A. Shherby`na, «New means of competencies assessing in moodle», Informacijni texnologiyi $i$ zasoby navchannya, т. 55, № 5, p. 96-104, 2016. (in Ukranian).

[17] V. G. Troyanovs 'ka, «Adaptive testing as an alternative method of controlling and evaluating the students' competences in higher education», Naukovy`j chasopy`s NPU imeni M. P. Dragomanova. Seriya 16. Tvorcha osoby`stist` uchy` telya: problemy` teoriyi i prakty`ky`, Vy`p.14 (24), p. 283-286, 2011. (in Ukranian).

[18] V. M. Soloshhenko, "Criteria for assessing the foreign language competence of foreign students in Germany at the request of exams (dsh, testdaf): comparative analysis», Naukovi zapy`sky`Sums`kogo derzhavnogo pedagogichnogo universy`tetu imeni A. S. Makarenka. Seriya "Filologichna”. Vy`p. 30, p. 253-257, 2012. (in Ukranian).

[19] V. S. Avanesov, «Pedagogical measurement of latent qualities», Pedagogicheskaya diagnostika. №4, p. 69-78, 2003. (in Russian).

[20] V. S. Avanesov, «The problem of pedagogical measurement of latent qualities», Pedagogicheskie izmereniya. № 3. p. 41-63, 2010. (in Russian). 
[21] R. I. Ostapenko, «Mathematical modeling of latent structures in psychology and sociology», Perspektivy nauki $i$ obrazovaniya. № 2, 2013. [online]. Avalaible: http://www.psychology-online.net/(in Russian).

[22] O. V. Mitina, «Modeling of the latent changes through structural equations», EHksperimental'naya psihologiya. №1, p. 131-148, 2008. (in Russian).

[23] A. A. Maslak, T. S. Anisimova, S. A. Osipov, A. I. Davletova, «Quality assessment of the questionnaire for measuring the latent variable «tolerance»», VI Vseros. nauch.-prakt. konf. Ocenka ehffektivnosti obrazovatel'nyh innovacij i tekhnologij, Slavyansk-na-Kubani, 2004. p. 25-35. (in Russian).

[24] A. R. ZHamalova, A. A. Maslak, «Measurement of the latent variable «motivation to success»», Nauch.-metod. ehlektronnyj zhurnal «Koncept», № 11, 2016. [online]. Avalaible: http://e-koncept.ru/2016/16234.htm. (in Russian).

[25] V. Andrushhenko, Strategy for reforming education in Ukraine. Ky`yiv, Ukrayina: K.I.S., 2003. (in Ukranian).

[26] N. M. Borytko, Teacher's diagnostic activity. Moskva, RF: Akademiya, 2006. (in Russian).

[27] E. A. Mihajlychev, Pedagogical tools of diagnosis and monitoring of educational process. Taganrog, RF: Izd-vo Taganrog. gos. ped. in-ta, 2005. (in Russian).

[28] S. E. SHishov, V. A. Kal'nej, Monitoring the quality of education at school. Moskva, RF: Pedagogicheskoe obshchestvo Rossii, 1999. (in Russian).

[29] V. P. Bespal'ko, YU. G. Tatur, Systematic and methodological provision of the educational process of specialists training. Moskva, RF: Vysshaya shkola, 1989. (in Russian).

[30] M. B. Yevtux, E. V. Luzik, ta L. M. Dy’bkova, Innovative methods of academic achievements evaluating. Ky`yiv, Ukrayina: KNEU, 2010. (in Ukranian).

[31] A. N. Majorov, The theory and practice of tests creating for the education system. Moskva, RF: Intellekt-Centr, 2001. (in Russian).

[32] O. O. Matvyeyeva, «To the problem of diagnosing the socio-professional competence of future music teachers», Naukovi zapy`sky`Berdyans`kogo derzhavnogo pedagogichnogo universy`tetu. Pedagogichni nauky`. Vy`p. 3, p.182-190, 2015. (in Ukranian).

[33] O. Yu. Kuznetsova, et al., Competence in English: typical tests. Kharkiv, Ukraina: Pravo, 2018. (in English).

[34] A. I. Migunov, I. B. Mikirtumov, i B. I. Fedorov, Logics. Moskva, RF: Prospekt, 2015. (in Russian).

Text of the article was accepted by Editorial Team 21.10.2018

\title{
ЗАСТОСУВАННЯ ІКТ У ПРОЦЕСІ ЕКСПЕРТНОГО ОЦІНЮВАННЯ ЛАТЕНТНИХ ЗМІННИХ У ПСИХОЛОГО-ПЕДАГОГІЧНИХ ДОСЛІДЖЕННЯХ
}

\author{
Матвєєва Ольга Олександрівна \\ доктор педагогічних наук, доцент, професор кафедри музично-інструментальної підготовки вчителя \\ Харківський національний педагогічний університет імені Г. С. Сковороди, м. Харків, Україна \\ ORCID ID 0000000306637726 \\ oamat@ukr.net
}

\section{Гриньова Валентина Миколаївна}

доктор педагогічних наук, професор, завідувач кафедри початкової, дошкільної та професійної освіти Харківський національний педагогічний університет імені Г. С. Сковороди, м. Харків, Україна ORCID ID 0000000230274622

kvn.grineva@gmail.com

\section{Кузнецова Олена Юріївна}

доктор педагогічних наук, професор, завідувач кафедри іноземних мов №3

Національний юридичний університет імені Ярослава Мудрого, м. Харків, Україна

ORCID ID 0000-0003-1156-1842

kvf2001@ukr.net

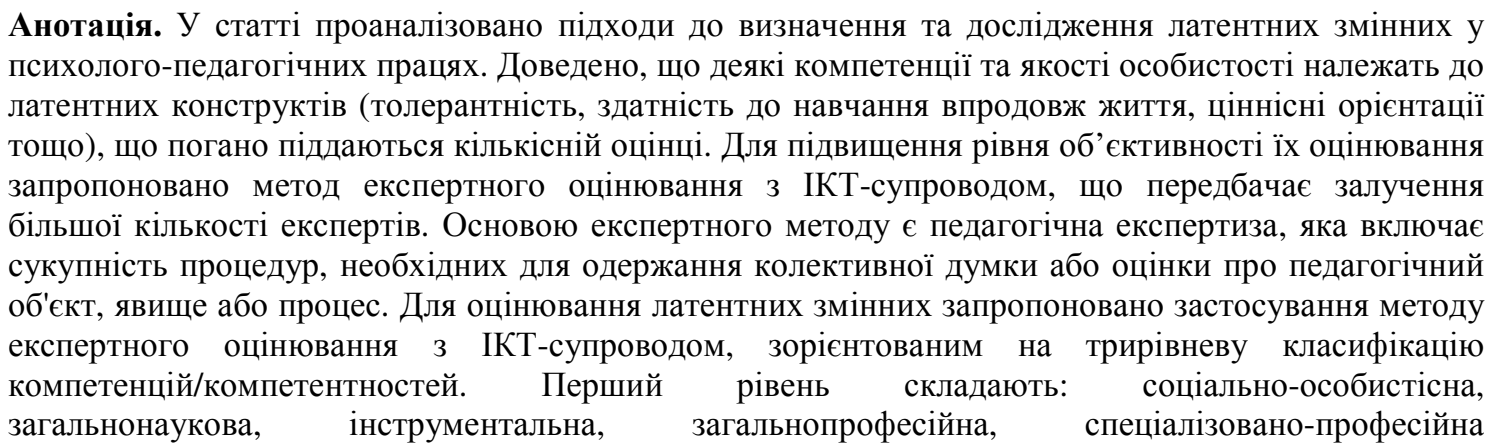


компетентності; другий рівень об’єднує компетенції, що входять до їх складу; третій рівень становлять складники компетенцій - знання, уміння, цінності, особистісні якості. Розроблений i запропонований ІКТ-супровід містить інформацію про Автора (розробника), Експертів, оцінки Експертів, значення, отримані в результаті обробки оцінок Експертів (коефіцієнти). Передбачено оцінювання Експертами значущості більш дрібних структурних одиниць щодо більших. Спочатку оцінюється сформованість кожної окремої компетентності відповідно до всієї соціальнопрофесійної компетентності у відсотках, приймаючи соціально-професійну компетентність за 100\%, потім оцінюється вагомість компетенцій, що входять до складу даної компетентності й значущість окремих складників компетенцій щодо відповідної компетенції.

Ключові слова: латентні змінні; класифікація компетенцій; метод експертного оцінювання; IКТоцінювання.

\title{
ПРИМЕНЕНИЕ ИКТ В ПРОЦЕССЕ ЭКСПЕРТНОГО ОЦЕНИВАНИЯ ЛАТЕНТНЫХ ПЕРЕМЕННЫХ В ПСИХОЛОГО-ПЕДАГОГИЧЕСКИХ ИССЛЕДОВАНИЯХ
}

\author{
Матвеева Ольга Александровна \\ доктор педагогических наук, доцент, профессор кафедры музыкально-инструментальной подготовки учителя \\ Харьковский национальный педагогический университет имени Г. С. Сковороды, г. Харьков, Украина \\ ORCID ID 0000000306637726 \\ oamat@ukr.net
}

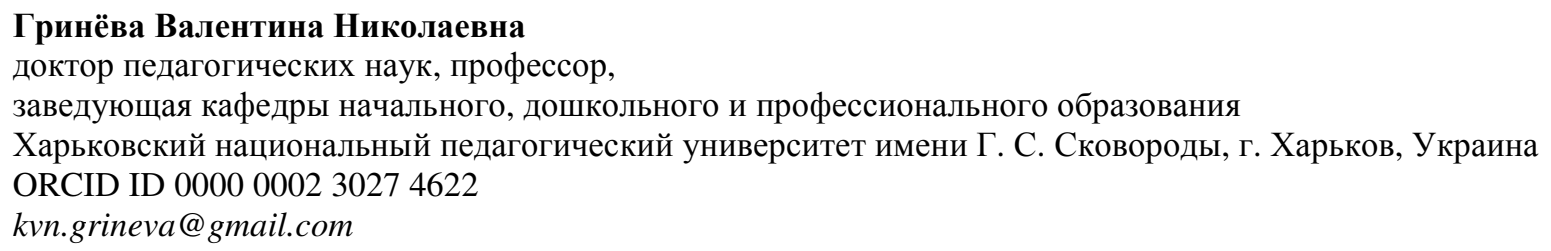

\section{Кузнецова Елена Юрьевна}

доктор педагогических наук, профессор, заведующая кафедры иностранных языков №3

Национальный юридический университет имени Ярослава Мудрого, г. Харьков, Украина

ORCID ID 0000-0003-1156-1842

kvf2001@ukr.net

\begin{abstract}
Аннотация. В статье проанализированы подходы к определению и изучению латентных переменных в психолого-педагогических исследованиях. Установлено, что некоторые компетенции и качества личности относятся к латентным конструктам (толерантность, способность к обучению в течение жизни, ценностные ориентации и т.д.) и плохо поддаются количественной оценке. Для повышения уровня объективности их оценивания предложен метод экспертного оценивания с ИКТ- сопровождением, что предполагает привлечение большего количества экспертов. Основой экспертного метода является педагогическая экспертиза, которая включает совокупность процедур, необходимых для получения коллективного мнения или оценки о педагогическом объекте, явлении или процессе. Для оценки латентных переменных предложено применение метода экспертного оценивания с ИКТ- сопровождением на основе трехуровневой классификации компетенций/компетентностей. Первый уровень составляют: социальноличностная, общенаучная, инструментальная, общепрофессиональная, специализированнопрофессиональная компетентности; второй уровень объединяет компетенции, входящие в их состав; третий уровень объединяет составляющие компетенций (знания, умения, ценности, личностные качества). Предложенное ИКТ-сопровождение содержит информацию об Авторе (разработчик); Экспертах; оценках Экспертов; значениях, полученных в результате обработки оценок Экспертов (коэффициенты). Предусмотрено оценивание Экспертами значимости более мелких структурных единиц относительно больших. Сначала оценивается сформированность каждой отдельной компетентности относительно социально-профессиональной компетентности в процентах, принимая последнюю за 100\%, затем оценивается значимость компетенций, входящих в состав данной компетентности и значимость отдельных составляющих компетенции.
\end{abstract}

Ключевые слова: латентные переменные; классификация компетенций; метод экспертного оценивания; ИКТ-оценивание.

\section{(cc) BY-NC-SA}

This work is licensed under Creative Commons Attribution-NonCommercial-ShareAlike 4.0 International License. 